\title{
Role of NMDA and Non-NMDA lonotropic Glutamate Receptors in Traumatic Spinal Cord Axonal Injury
}

\author{
Sandeep K. Agrawal and Michael G. Fehlings \\ Spinal Cord Injury Neurophysiology Laboratory, Playfair Neuroscience Unit, Toronto Hospital Research Institute, \\ University of Toronto, Toronto, Ontario, Canada M5T 2S8
}

\begin{abstract}
We examined the role of glutamatergic mechanisms in acute injury to rat spinal cord white matter. Compound action potentials (CAPs) were recorded from isolated dorsal column segments in vitro. Under control conditions (Ringer's solution), the CAPs decreased to $71.4 \pm 2.0 \%$ of preinjury values after compression injury with a clip exerting a closing force of $2 \mathrm{~g}$. The combination of the NMDA receptor blocker APV $(50 \mu \mathrm{M})$ and the AMPA/kainate (KA) receptor blocker CNQX $(10 \mu \mathrm{M})$ resulted in significantly improved recovery of CAP amplitude postinjury; however, the NMDA receptor antagonist APV alone did not enhance postinjury recovery, and infusion of NMDA (10 $\mu \mathrm{M})$ did not affect recovery of the CAPs. In contrast, the AMPA/KA receptor blockers NBQX $(10 \mu \mathrm{M})$ or CNQX $(10 \mu \mathrm{M})$ significantly enhanced the recovery of CAP amplitude postinjury. The agonists AMPA $(100 \mu \mathrm{M})$ or KA $(100 \mu \mathrm{M})$ resulted in
\end{abstract}

significant attenuation of CAP amplitude postinjury. Coapplication of AMPA/KA plus NBQX and CNQX was also associated with improved functional recovery. After incubation with AMPA and $\mathrm{KA}, \mathrm{Co}^{2+}$-positive glia were visualized in spinal cord white matter. Similar results were seen after compressive injury but not in control cords. Immunohistochemistry and Western blot analysis demonstrated AMPA (GluR4)- and KA (GluR6/7 and KA2)-positive astrocytes in spinal cord white matter. In summary, non-NMDA ionotropic glutamate receptors seem to be involved in the pathophysiology of traumatic spinal cord injury. The presence of AMPA (GluR4) and KA (GluR6/7 and KA2) receptors on periaxonal astrocytes suggests a role for these cells in glutamatergic white matter injury.

Key words: rat; spinal cord injury; calcium; NMDA; AMPA/ kainate; cobalt; immunocytochemistry; axons; glia
There is considerable evidence that alterations in membrane permeability attributable to sodium and calcium are an important feature in the pathogenesis of neuronal degeneration after injury to the CNS (Bengtsson and Siesjo, 1990; Tator and Fehlings, 1991; Agrawal and Fehlings, 1996); however, the mechanisms for posttraumatic fluxes in ion gradients appear to differ in neuronal somata and axons (Regan and Choi, 1991). Although NMDAtype glutamate receptors have been closely linked to neuronal calcium-dependent cytotoxicity (Goldberg and Choi, 1993), the mechanisms of cation-dependent axonal injury after spinal cord trauma have not been elucidated fully.

The NMDA receptors are highly $\mathrm{Ca}^{2+}$ permeable, whereas non-NMDA glutamate receptors, activated by the agonists kainate (KA) and AMPA, have traditionally been viewed as $\mathrm{Ca}^{2+}$. impermeable and permeable to monovalent ions such as $\mathrm{Na}^{+}$and $\mathrm{K}^{+}$(Ascher and Nowak, 1988; Mayer et al., 1988). Accordingly, non-NMDA receptors have been believed to cause $\mathrm{Ca}^{2+}$ influx only indirectly by $\mathrm{Na}^{+}$-dependent depolarization, with subsequent opening of voltage-gated $\mathrm{Ca}^{2+}$ channels. It is now clear, however, that several types of AMPA/KA receptors are directly $\mathrm{Ca}^{2+}$ permeable and that these receptors can be important sources of $\mathrm{Ca}^{2+}$ influx in neurons (Holopainen et al., 1989; Iino et al., 1990;

Received Oct. 11, 1996; revised Oct. 30, 1996; accepted Nov. 6, 1996.

This work was supported by grants from the Medical Research Council of Canada and Physicians Services Incorporated (PSI) Foundation. M.G.F. is supported by a Career Investigator Award from the Ontario Ministry of Health. We thank Judy E. Trogadis for help with the confocal imaging. The technical assistance of Karen Scales and critical comments of Dr. L. Zhang and Raad Nashmi are gratefully acknowledged.

Correspondence should be addressed to Dr. Michael G. Fehlings, Playfair Neuroscience Unit, McLaughlin Pavilion, Room 12-411, Toronto Hospital (Western Division), 399 Bathurst Street, Toronto, Ontario, Canada M5T 2S8.

Copyright (C) 1997 Society for Neuroscience $0270-6474 / 97 / 171055-09 \$ 05.00 / 0$
Gilbertson et al., 1991; Pruss et al., 1991) and astrocytes (Glaum et al., 1990; Jensen and Chiu, 1991; Burnashev et al., 1992b). Additionally, the cloning of several non-NMDA glutamate receptor subtypes has revealed that when combinations of these are expressed in oocytes or cell lines, they can give rise to glutamate receptors that are either $\mathrm{Ca}^{2+}$ permeable or $\mathrm{Ca}^{2+}$ impermeable (Hollman et al., 1991; Miller, 1991). Recent experimental evidence supports a role for non-NMDA-type glutamate receptors gated by AMPA and KA in the pathophysiology of spinal cord injury (SCI) in vivo (Wrathall et al., 1994, 1996). Accordingly, although KA toxicity was originally thought to be relatively axon sparing (Olney, 1981; Coyle, 1983), these studies suggest a role for non-NMDA receptors in acute SCI. A detailed understanding of the mechanisms of traumatic white matter injury would be of central importance in designing more effective neuroprotective strategies for SCI.

In the present study, we have examined the role of NMDA and non-NMDA ionotropic glutamate receptors in mediating traumatic axonal injury in an in vitro model of compressive spinal cord trauma. We report evidence that spinal cord white matter injury occurs in part through the activation of non-NMDA ionotropic glutamate receptors. By Western blot and immunocytochemistry, AMPA (GluR4) and KA (GluR6/7 and KA2) receptors were identified on astrocytes in spinal cord white matter.

A preliminary version of this work has been published previously in abstract form (Agrawal and Fehlings, 1995).

\section{MATERIALS AND METHODS}

Experimental preparation. Experiments were performed on 93 dorsal column segments obtained from adult male Wistar rats $(250-350 \mathrm{gm})$ ranging in age from 4 to 11 months. After the rats were anesthetized with sodium pentobarbital $(40 \mathrm{mg} / \mathrm{kg}$, i.p.), a laminectomy was performed 
between T3 and T10 to expose the spinal cord. A $25 \mathrm{~mm}$ section of cord was removed rapidly and placed in cold $\left(4-7^{\circ} \mathrm{C}\right)$ Ringer's solution. The spinal cord segment was hemisected, and the dorsal column was sectioned longitudinally with microscissors. The dorsal column segment was pinned in an in vitro recording chamber and was perfused constantly $(2-5 \mathrm{ml} / \mathrm{min}$ drip rate) with Ringer's solution bubbled with $95 \% \mathrm{O}_{2} / 5 \% \mathrm{CO}_{2}$. The bath medium temperature was maintained at $25 \pm 0.5^{\circ} \mathrm{C}$ with a microprocessor-controlled thermistor (Omega CN9000). Selected experiments $(n=11)$ were performed at $33^{\circ} \mathrm{C}$ to verify key results at a higher temperature.

A bipolar platinum wire stimulating electrode was placed on one end of the dorsal column segment, and it delivered a $100 \mu \mathrm{sec}$ constant current pulse at a supramaximal stimulus intensity, which was $50 \%$ greater than that required to elicit a maximal response. The responses were recorded extracellularly by two glass microelectrodes $(2-4 \mu \mathrm{m}$ tip, 5-10 $\mathrm{M} \Omega$ resistance) filled with $150 \mathrm{mM} \mathrm{KCl}$. The signals were amplified $100 \times$ (Axoprobe-1A, Axon Instruments), digitized (ISC-16 A/D converter, R. C. Electronics) at 12 bit resolution, and stored on a microcomputer and VCR. Each sweep of recording had a duration of $8 \mathrm{msec}$ and was digitized to 512 points (i.e., sampling rate of $64 \mathrm{kHz}$ ).

Experimental protocol. The dorsal column segment was allowed to stabilize for $90 \mathrm{~min}$ after dissection before the experiment was started. A set of recordings was obtained consisting of 100 sweeps at $0.2 \mathrm{~Hz}$. After the control set of recordings, the drug or ion-substituted solutions were infused $15 \mathrm{~min}$ before injury. Then the dorsal column segment was injured between the proximal and distal recording sites for $15 \mathrm{sec}$ with a $2 \mathrm{~g}$ modified aneurysm clip (1 mm wide) (Dolan and Tator, 1979; Fehlings and Nashmi, 1995; Agrawal and Fehlings, 1996). The drug infusion was continued at least 20 min after injury and then substituted with Ringer's solution. Response recovery was monitored for at least $2 \mathrm{hr}$ after injury. The same set of control experiments was used for all groups.

$\mathrm{Co}^{2+}$ staining of hemisected spinal cord slices for the presence of $A M P A / K A$ receptors. A $30 \mathrm{~mm}$ segment of thoracic cord was excised and hemisected in eight male Wistar rats. We used the $\mathrm{Co}^{2+}$-uptake staining method of Pruss et al. (1991), with certain modifications, to visualize the presence of AMPA/KA receptors in spinal cord white matter. AMPA/KA stimulation (100 $\mu \mathrm{M}$ kainic acid plus $100 \mu \mathrm{M}$ AMPA) or compressive injury with a clip exerting a closing force of $2 g$ or blocking with NBQX $(10 \mu \mathrm{M})$ plus CNQX $(10 \mu \mathrm{M})$ was performed at room temperature for 20 min in $5 \mathrm{mM} \mathrm{CoCl}_{2}$. $\mathrm{Co}^{2+}$ was precipitated in $1.0 \%\left(\mathrm{NH}_{4}\right)_{2} \mathrm{~S}$ for $5 \mathrm{~min}$. The hemisected cord was post-fixed in $4 \%$ phosphate-buffered formalin for $1 \mathrm{hr}$ and snap-frozen in isopentane. Fifteen micrometer sections were cut with a cryostat and mounted on slides. Silver enhancement of $\mathrm{Co}^{2+}$ was performed at $45^{\circ} \mathrm{C}$ for $30 \mathrm{~min}$ in a solution of $0.1 \% \mathrm{AgNO}_{3}, 292 \mathrm{~mm}$ sucrose, $15.5 \mathrm{~mm}$ hydroquinone, and $42 \mathrm{~mm}$ citric acid, according to the methodology of Pruss et al. (1991).

Western blot analysis of spinal cord white matter. Crude membrane fractions of dorsal column white matter [exclusion of gray matter confirmed by microtubular-associated protein (MAP2; Burgoyne, 1991) immunoblotting; see Figure $6 a$ ] were isolated according to the method of Roberts-Lewis et al. (1994). Briefly, the spinal cord white matter was homogenized in $\sim 10$ vol of $50 \mathrm{~mm}$ Tris- $\mathrm{HCl}$ ( $4 \mathrm{~mm}$ EDTA, pH 7.4, containing $1 \mu \mathrm{M}$ pepstatin, $100 \mu \mathrm{M}$ leupeptin, $100 \mu \mathrm{M}$ phenylmethylsulfonylfluoride, and $10 \mu \mathrm{g} / \mathrm{ml}$ aprotinin) at $4^{\circ} \mathrm{C}$. Samples were centrifuged at $400 \times g$ for $5 \mathrm{~min}$. The pellet was discarded, and the supernatant was centrifuged at $40,000 \times g$ for $20 \mathrm{~min}$ at $4^{\circ} \mathrm{C}$. The pellet was taken as the crude membrane fraction and was washed with Tris buffer containing 2 mM $\beta$-mercaptoethanol and resuspended. Protein quantification was performed by the modified Lowry method (Peterson, 1977). Discontinuous SDS-PAGE was performed using a Bio-Rad mini-protein II electrophoresis cell. For each rat, $10 \mu \mathrm{g}$ of membrane fraction protein was electrophoresed and electroblotted onto supported nitrocellulose membranes. Blots were blocked $(1 \mathrm{hr})$ with $0.5 \%$ nonfat dry milk/ $0.1 \%$ Tween 20 in Tris-buffered saline (TBS) at room temperature and then incubated (1 hr) with rabbit polyclonal antibodies against GluR1, GluR2/3, GluR4, GluR6/7, and KA2 (Upstate Biotechnology, Lake Placid, NY) diluted $(1: 200)$ in blocking buffer. Blots were incubated with horseradish peroxidase (HRP)-conjugated goat anti-rabbit (1:4000). After several washes with TBS, immunoreactive proteins were visualized with an enhanced electrochemiluminescence kit (ECL, Amersham, Arlington Heights, IL). Immunoblots of olfactory bulb were used as positive controls for GluR1 and GluR2/3 labeling. To verify that equal amounts of protein were loaded in each lane, the same membranes were reblocked ( $1 \mathrm{hr})$ with $0.5 \%$ nonfat dry milk/ $0.1 \%$ Tween 20 in TBS at room temperature and then incubated $(1 \mathrm{hr})$ with mouse monoclonal antibody against Neuro- filament 200 (Sigma, St. Louis, MO) diluted (1:4000) in blocking buffer. The blots were reincubated with HRP-conjugated goat anti-mouse (1: 4000), washed with TBS, and revisualized by ECL.

Immunohistochemistry of spinal cord white matter. Immunohistochemistry was performed according to the method of Martin et al. (1993) in four male Wistar rats. Briefly, after transcardiac perfusion-fixation (4\% paraformaldehyde $/ 0.1 \%$ glutaraldehyde with $15 \%$ picric acid) the spinal cord $(n=4)$ was removed and frozen in isopentane chilled by dry ice. Transverse and longitudinal $10 \mu \mathrm{m}$ frozen sections were cut on a cryostat at $-18^{\circ} \mathrm{C}$, mounted on poly-L-lysine-subbed slides, and dried overnight under vacuum with desiccant. Sections were washed and permeabilized for $30 \mathrm{~min}$ in TBS containing $4 \%$ heat-inactivated goat serum and $0.4 \%$ Triton X-100. The primary antibodies were diluted $(1: 200)$ in PBS/ $/ 1 \%$ Triton X-100 and used to incubate slides for $48 \mathrm{hr}$ at $4^{\circ} \mathrm{C}$ in rabbit polyclonal anti-GluR1, GluR2/3, GluR4, GluR6/7, and KA2 (Upstate Biotechnology) and mouse monoclonal glial fibrillary acidic protein (GFAP) (Dimension Laboratories, Mississauga, Ontario, Canada). After successive washes in TBS, the slides were incubated for $30 \mathrm{~min}$ in Fluorescent-conjugated $2^{\circ}$ antibody fluorescein isothiocyanate (FITC; Molecular Probes, Eugene, OR) for AMPA/KA receptors and in Texas Red for GFAP to identify astrocytes. Control sections were incubated only with the secondary antibody or only with primary antibody. Imaging was performed using a laser confocal microscope (Bio-Rad MRC 600; Bio-Rad, Mississauga, Ontario, Canada) with a krypton-argon ion laser light source and equipped with a Nikon Optiphot upright microscope.

Solutions and drugs. The perfused solutions were bubbled continuously with $95 \% \mathrm{O}_{2} / 5 \% \mathrm{CO}_{2}$. The composition of perfused solutions was (in $\mathrm{mM}$ ): Ringer's-124 NaCl, $3 \mathrm{KCl}, 1 \mathrm{Na}_{2} \mathrm{HPO}_{4}, 26 \mathrm{NaHCO}_{3}, 1.5 \mathrm{MgSO}_{4}, 1.5$ $\mathrm{CaCl}_{2}$, and 10 glucose; zero calcium-124 NaCl, $3 \mathrm{KCl}, 1 \mathrm{Na}_{2} \mathrm{HPO}_{4}, 26$ $\mathrm{NaHCO}_{3}, 1.5 \mathrm{MgSO}_{4}, 1.5$ EGTA, and 10 glucose. NMDA (10 and $100 \mu \mathrm{M}$ with $10 \mu \mathrm{M}$ glycine), AMPA $(100 \mu \mathrm{M})$, kainic acid $(100 \mu \mathrm{M})$, APV (50 $\mu \mathrm{M})$, CNQX [10 $\mu \mathrm{M}$ (Research Biochemicals, Natick, MA)], and NBQX $[10 \mu \mathrm{M}$ (Tocris Cookson)] were dissolved in aqueous solution $(0.1 \mathrm{~N}$ $\mathrm{NaOH}$ and titrated with $\mathrm{HCl}, \mathrm{pH}$ 8.0) and then dissolved in Ringer's solution. The $\mathrm{pH}$ of the solutions was maintained at 7.4 and the osmolarity at $290-310$.

Data analysis and statistics. Peak-to-peak amplitude of the individual compound action potentials (CAPs) was analyzed by computer after completion of the experiment (Fehlings and Nashmi, 1995; Agrawal and Fehlings, 1996). All data were expressed as the mean \pm SE. Significant differences in amplitude (at $p<0.05$ ) between control (Ringer's solution) and treatment CAPs at a particular time point of the experiment were determined post hoc by the Student Newman-Keuls test after two-way ANOVA. The same set of control experiments was used for all groups, except for data collected at $33^{\circ} \mathrm{C}$ in which separate controls were generated.

\section{RESULTS}

\section{Role of ionotropic glutamate receptors in compressive SCI}

Experiments were performed to determine whether ligand-gated ionotropic glutamate receptors are involved in the pathophysiology of traumatic SCI. The NMDA receptor blocker APV $(50 \mu \mathrm{M})$ and the AMPA/KA receptor blocker CNQX $(10 \mu \mathrm{M})$ were added to the perfusate to examine for ionotropic glutamatergic effects. The APV+CNQX solution was started 15 min before the $2 g$ clip compression injury and continued until $20 \mathrm{~min}$ after injury. Recovery of CAP amplitude was observed for $2 \mathrm{hr}$ after injury. With the combined administration of APV and CNQX, the recovery of CAP amplitude was significantly improved $(91.5 \pm 6.4 \%$ of preinjury values) as compared with Ringer's solution (71.4 $\pm 2.0 \%$ of preinjury; $p<0.05$ ) at $1 \mathrm{hr}$ after injury (Fig. 1). Representative recordings are shown in Figure $1 a-c$; a graph of normalized CAP amplitude versus time is shown in Figure $1 d$.

\section{Role of NMDA receptors in traumatic SCI}

To determine to what extent NMDA receptors mediate traumatic spinal cord axonal injury, we examined the effect of the agonist NMDA (10 $\mu \mathrm{M}, n=6 ; 100 \mu \mathrm{M}, n=5)$ and the selective NMDA antagonist APV $(50 \mu \mathrm{M} ; n=6)$. As shown in Figure $2 a$, admin- 

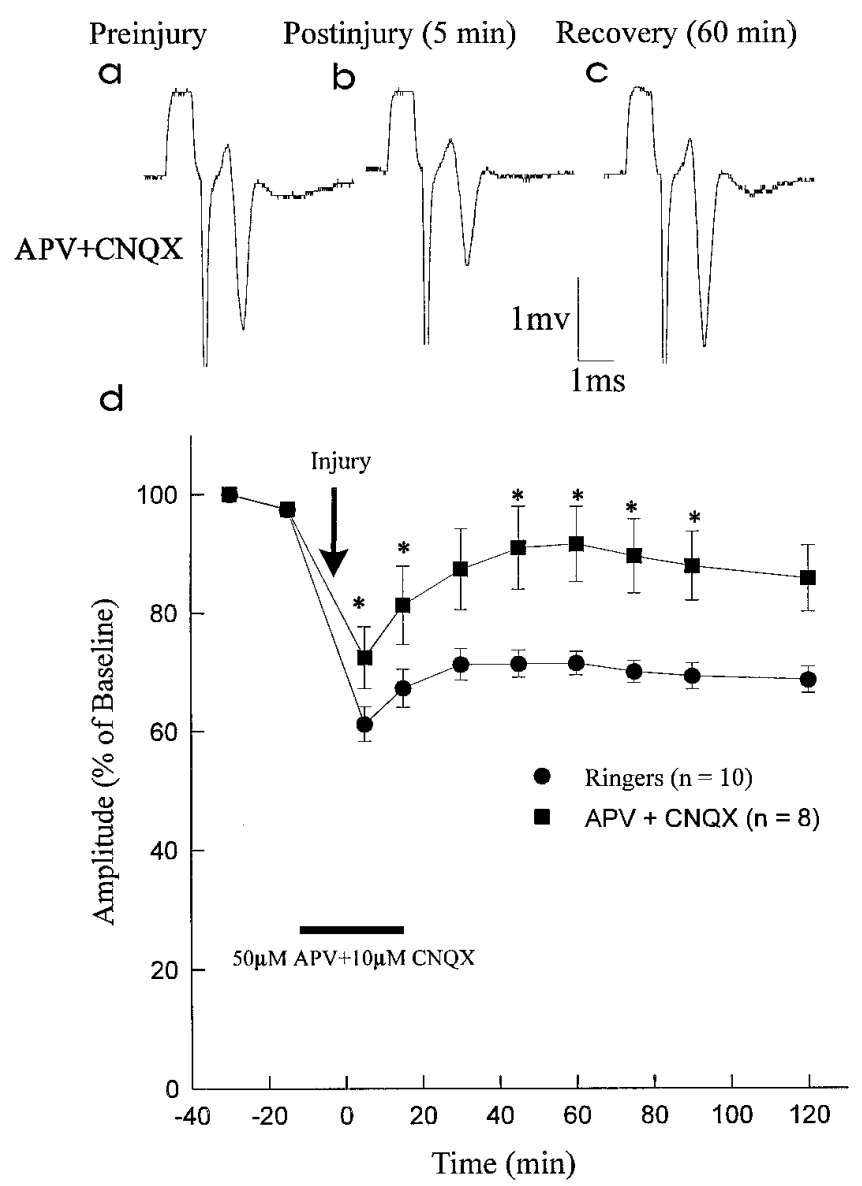

Figure 1. Effect of ionotropic glutamate receptor blockade on recovery of CAP amplitude after compressive injury. APV (50 $\mu \mathrm{M}$; NMDA receptor blocker) and CNQX (10 $\mu \mathrm{M}$; AMPA/KA receptor blocker $)$ $(A P V+C N Q X)$ were administered in combination and compared with control Ringer's solution (Ringers). $a-c$, Representative CAP waveforms from the $A P V+C N Q X$ group recorded preinjury, 5 min postinjury, and 60 min postinjury (during washout with Ringer's solution). $d$, Graph of normalized CAP amplitude versus time. Combined administration of APV $(50 \mu \mathrm{M})$ and CNQX $(10 \mu \mathrm{M})$ resulted in improved CAP amplitude recovery postinjury (significant differences in CAP amplitude shown by asterisks). At 60 min postinjury, the CAP amplitude in the $A P V+C N Q X$ group had recovered to $91.5 \pm 6.4 \%$ of preinjury values as compared with the Ringers group $(71.4 \pm 2.0 \%$ of preinjury).

istration of NMDA did not exacerbate the effects of traumatic injury. Moreover, the NMDA blocker APV did not improve the recovery of CAP amplitude after compressive trauma to the dorsal column segment (Fig. $2 b$ ).

\section{Role of AMPA/KA receptors in traumatic SCI}

Experiments were performed to determine the role of AMPA/KA receptors in traumatic SCI. The effect of the selective AMPA/KA receptor blockers NBQX $(10 \mu \mathrm{M})$ and CNQX $(10 \mu \mathrm{M})$ and coapplication of AMPA/KA plus antagonists was examined. NBQX, CNQX, or AMPA/KA plus NBQX and CNQX was administered 15 min before the $2 g$ clip compression injury and continued until 20 min after injury. Recovery of CAP amplitude was observed for $2 \mathrm{hr}$ after injury. NBQX, CNQX, and coapplication of antagonists resulted in significant enhancement of CAP recovery $(85.6 \pm$ $2.7 \%, 86.5 \pm 3.9 \%$, and $88.2 \pm 7.8 \%$ of preinjury values, respectively) as compared with Ringer's solution (71.4 $\pm 2.0 \%$ of preinjury value; $p<0.05$ ) at $1 \mathrm{hr}$ postinjury. Graphs of normalized CAPs versus time are shown in Figure $3 a-c$.

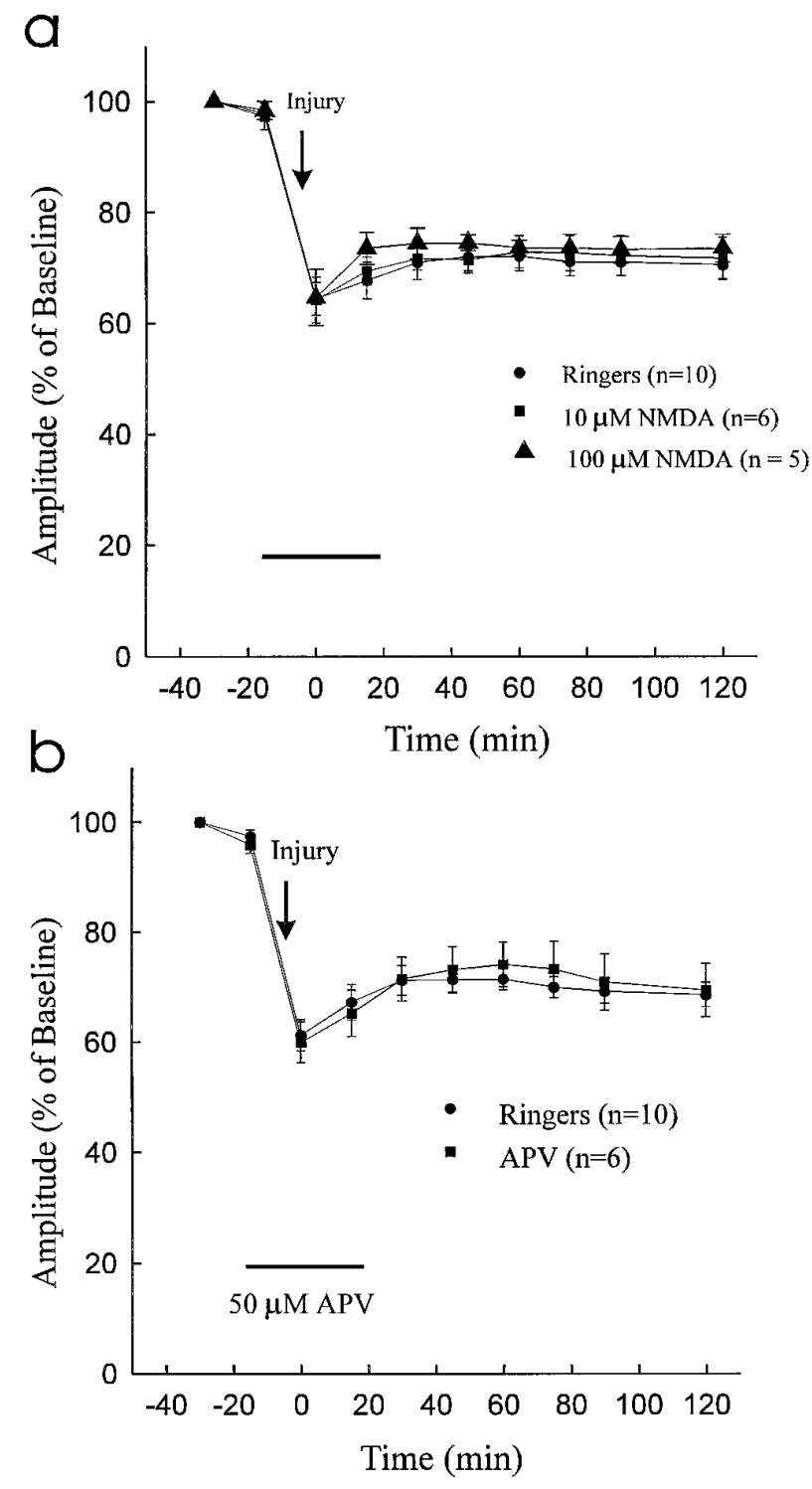

Figure 2. $a$, Administration of NMDA $(10 \mu \mathrm{M}$ and $100 \mu \mathrm{M})$ did not attenuate CAP recovery after traumatic injury. $b$, The NMDA receptor antagonist APV $(50 \mu \mathrm{M})$ did not improve recovery of CAP amplitude after compressive injury to the dorsal column segment.

To provide further evidence to support a role for AMPA/KA receptor activation in the pathophysiology of traumatic SCI, the effect of the agonists AMPA (10 and $100 \mu \mathrm{M})$ and kainic acid (10 and $100 \mu \mathrm{M})$ was examined. Infusion of the test solutions commenced 15 min before the $2 \mathrm{~g}$ clip compression injury and continued until $20 \mathrm{~min}$ after injury. The effects on CAP amplitude were observed for $2 \mathrm{hr}$ after injury. Infusion of AMPA (100 $\mu \mathrm{M})$ and kainic acid $(100 \mu \mathrm{M})$ significantly attenuated the recovery of CAP amplitude to $59.4 \pm 1.3 \%(p<0.05 ; n=5)$ and $59.0 \pm 1.6 \%$ $(p<0.05 ; n=5)$ of preinjury values, respectively, as compared with control Ringer's solution $(71.4 \pm 2.0 \% ; p<0.05)$ (Fig. 4a,b). Lower doses of AMPA or kainic acid $(10 \mu \mathrm{M})$ did not attenuate $(p>0.05)$ the recovery of CAP amplitude (data not shown). As an additional control, the effect of AMPA and kainic acid on the uninjured dorsal column segment ( $n=3$; Fig. 4) was observed. Both AMPA and kainic acid attenuated the CAP amplitude to $86.0 \pm 0.8 \%(p<0.05)$ and $85.4 \pm 1.2 \%(p<0.05)$ of control 

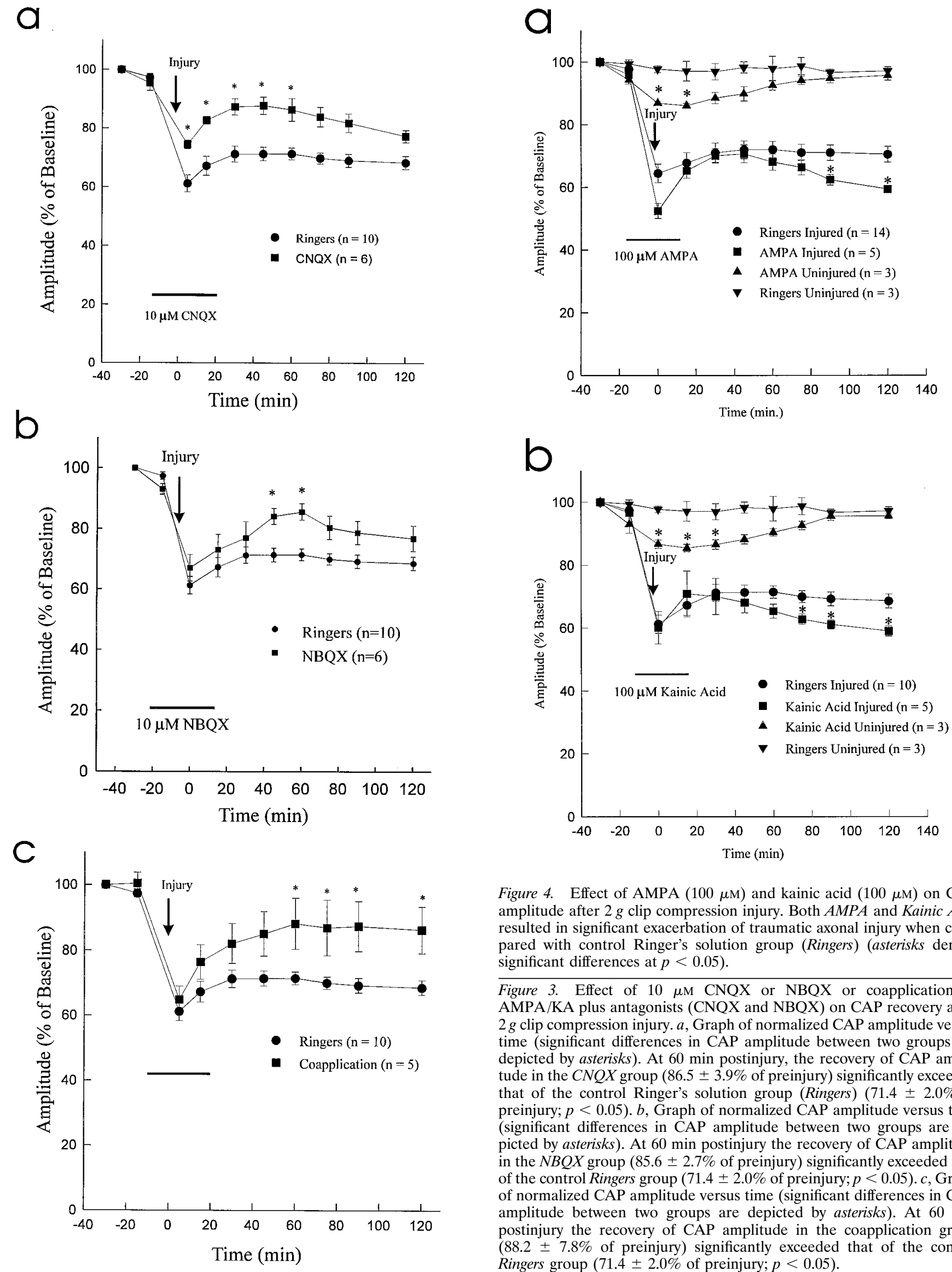

Figure 4. Effect of AMPA $(100 \mu \mathrm{M})$ and kainic acid $(100 \mu \mathrm{M})$ on CAP amplitude after $2 g$ clip compression injury. Both AMPA and Kainic Acid resulted in significant exacerbation of traumatic axonal injury when compared with control Ringer's solution group (Ringers) (asterisks denote significant differences at $p<0.05$ ).

Figure 3. Effect of $10 \mu \mathrm{M}$ CNQX or NBQX or coapplication of AMPA/KA plus antagonists (CNQX and NBQX) on CAP recovery after $2 g$ clip compression injury. $a$, Graph of normalized CAP amplitude versus time (significant differences in CAP amplitude between two groups are depicted by asterisks). At 60 min postinjury, the recovery of CAP amplitude in the $C N Q X$ group ( $86.5 \pm 3.9 \%$ of preinjury) significantly exceeded that of the control Ringer's solution group (Ringers) $(71.4 \pm 2.0 \%$ of preinjury; $p<0.05$ ). $b$, Graph of normalized CAP amplitude versus time (significant differences in CAP amplitude between two groups are depicted by asterisks). At $60 \mathrm{~min}$ postinjury the recovery of CAP amplitude in the $N B Q X$ group $(85.6 \pm 2.7 \%$ of preinjury) significantly exceeded that of the control Ringers group $(71.4 \pm 2.0 \%$ of preinjury; $p<0.05)$. $c$, Graph of normalized CAP amplitude versus time (significant differences in CAP amplitude between two groups are depicted by asterisks). At $60 \mathrm{~min}$ postinjury the recovery of CAP amplitude in the coapplication group $(88.2 \pm 7.8 \%$ of preinjury) significantly exceeded that of the control Ringers group $(71.4 \pm 2.0 \%$ of preinjury; $p<0.05)$. 

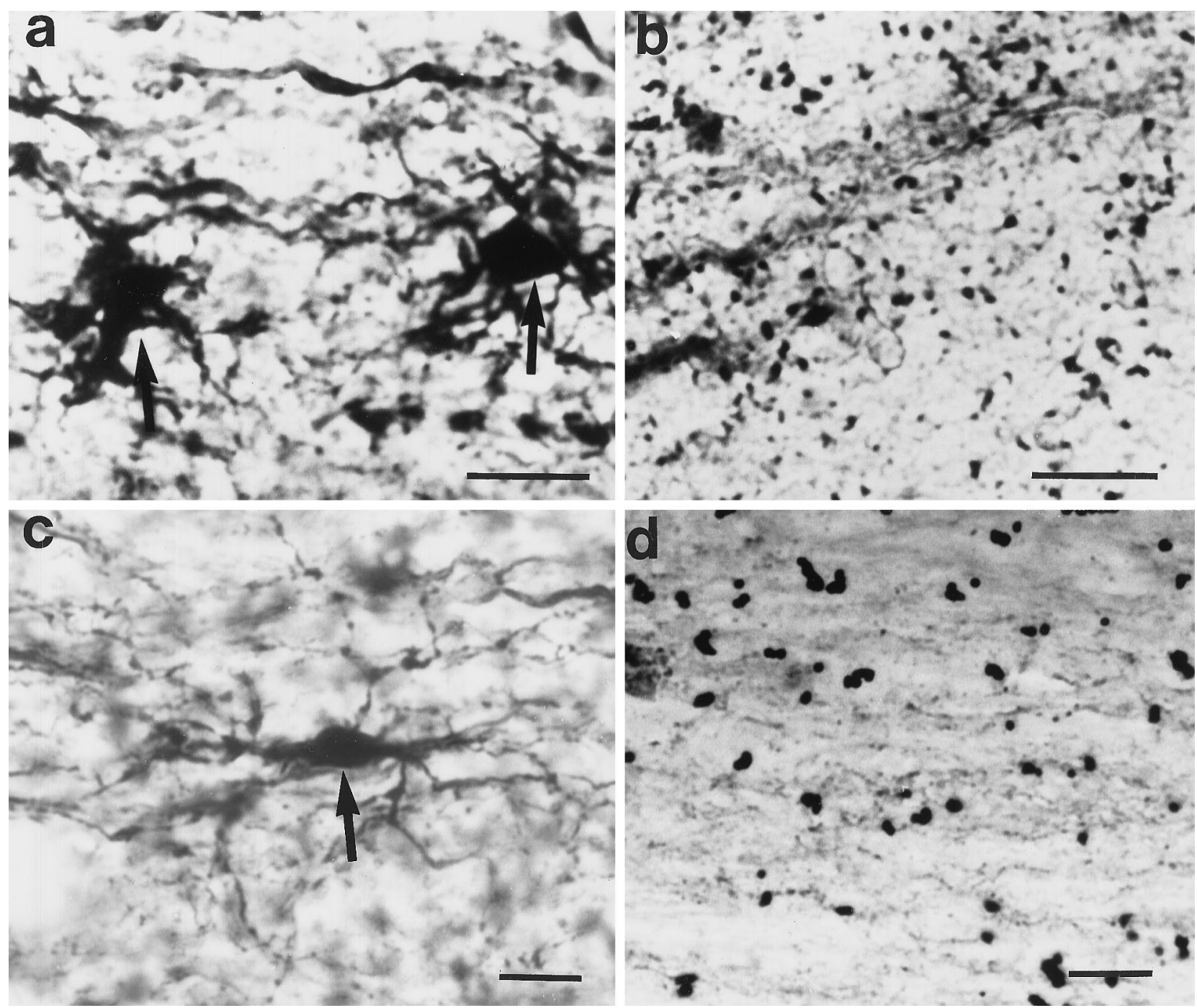

Figure 5. Longitudinal sections through spinal cord dorsal column stained for AMPA/KA receptors by the Co ${ }^{2+}$ uptake technique. Scale bar, 20 $\mu \mathrm{m}$. $a$, Two darkly stained astrocytes are shown (arrows). Section incubated with $100 \mu \mathrm{M}$ kainic acid and $100 \mu \mathrm{M}$ AMPA before histochemical processing. $b$, Control section (without AMPA/KA stimulation) of spinal cord dorsal column white matter showing background staining only. $c$, A darkly stained astrocyte is shown (arrow) in injured dorsal column (untreated with AMPA/KA). $d$, A dorsal column white matter preparation treated with CNQX and NBQX after clip compression injury showing no $\mathrm{Co}^{2+}$ uptake staining.

values, respectively. During washout with Ringer's solution, CAP amplitude of the uninjured dorsal column segments returned to baseline levels and remained stable.

The aforementioned experiments were conducted at $25^{\circ} \mathrm{C}$, because at this temperature the dorsal column preparation remains extremely stable physiologically (Agrawal and Fehlings, 1996). To confirm that the results described above could be replicated at more physiological temperatures, a number of experiments $(n=11)$ were conducted at $33^{\circ} \mathrm{C}$. The CNQXcontaining solution conferred a significant enhancement of CAP recovery $(77.5 \pm 1.8 \%)$ as compared with Ringer's solution $(64.8 \pm 3.2 \%$ of preinjury value; $p<0.05)$. The extent of neuroprotection between Ringer's solution and drug treatment was similar at $25^{\circ} \mathrm{C}$ and $33^{\circ} \mathrm{C}$.

\section{$\mathrm{Co}^{2+}$ uptake in spinal cord slices}

$\mathrm{Ca}^{2+}$-permeable AMPA/KA receptors in oocytes are permeable to $\mathrm{Co}^{2+}$ (McGurk et al., 1991), which does not permeate voltagesensitive $\mathrm{Ca}^{2+}$ channels (Hagiwara and Byerly, 1981), NMDA receptors (Mayer and Westbrook, 1987), or $\mathrm{Ca}^{2+}$-impermeable AMPA/KA receptors (Gu and Huang, 1991). Using a histochemical silver-staining method to identify $\mathrm{Co}^{2+}$ uptake, Pruss et al. (1991) showed that stimulation with kainic acid causes $\mathrm{Co}^{2+}$ influx through $\mathrm{Ca}^{2+}$-permeable AMPA/KA receptors in neurons. Using this method, we found that $\mathrm{Co}^{2+}$ positively stained glia in spinal cord white matter after incubation with $100 \mu \mathrm{M}$ kainic acid and $100 \mu \mathrm{M}$ AMPA or after compressive injury alone (Fig. 5a,c). The postinjury $\mathrm{Co}^{2+}$ uptake was blocked by applying the antagonists NBQX $(10 \mu \mathrm{M})$ and CNQX $(10 \mu \mathrm{M})$ and is shown in Figure $5 d$. In contrast, control spinal cord white matter sections (without AMPA/KA stimulation) showed only low levels of background staining (Fig. 5b).

\section{Immunoblotting of spinal cord white matter}

By Western blot, membrane preparations of rat spinal cord white matter (exclusion of gray matter confirmed by MAP2 immunoblotting; Fig. 6a) were reacted with antibodies against GluR1, GluR2/3, GluR4, GluR6/7, and KA2 after enzymatic deglycosy- 

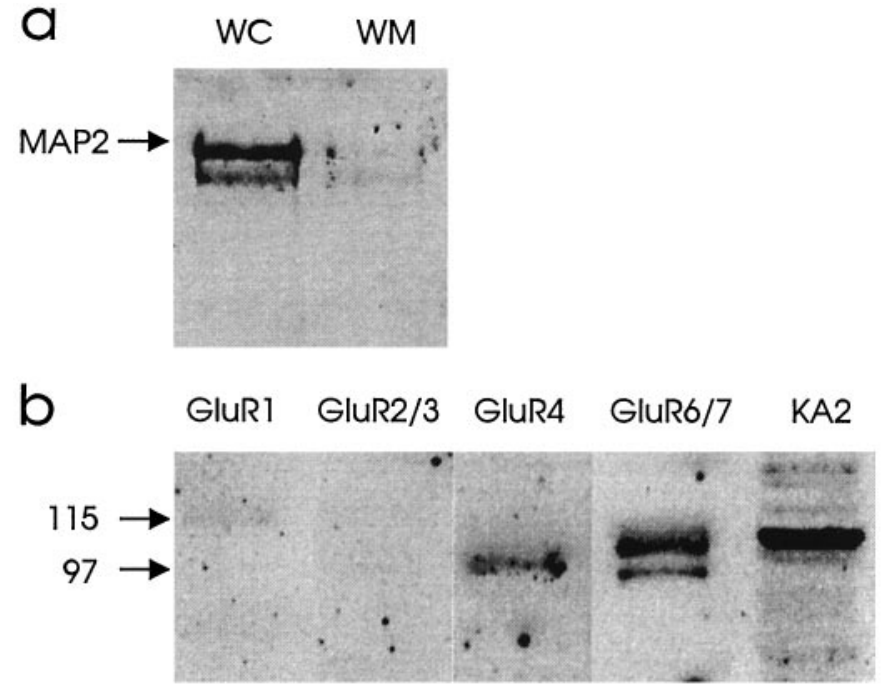

C

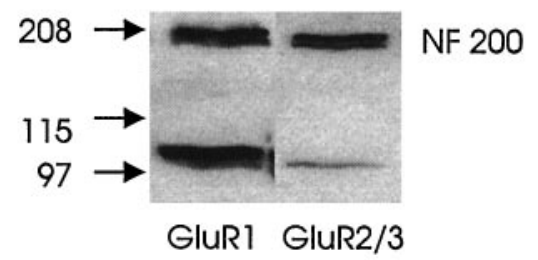

Figure 6. $a$, Western blot illustrating MAP2 presence in whole spinal cord $(W C)$ and exclusion in an isolated dorsal column white matter preparation $(W M) . b$, Spinal cord white matter (dorsal column) homogenates (10 $\mu \mathrm{g}$ protein) were subjected to SDS-PAGE and immunoblotted with antibodies to GluR1, GluR2/3, GluR4, GluR6/7, and KA2. As illustrated, GluR4, GluR6/7, and KA2 were detected in spinal cord white matter. $c$, These immunoblots show equal amounts of protein loading with NF 200 and positive controls for GluR1 and GluR2/3 using olfactory bulb.

lation. Immunoblotting after SDS-PAGE demonstrated that GluR4, GluR6/7, and KA2 antibodies were detected with distinct bands at molecular weights ranging from 97,000 to 115,000 (Fig. $6 b)$. In contrast, GluR1 and GluR2/3 were not detected. Immunoblots of olfactory bulb were used as positive controls for GluR1 and GluR2/3 labeling (Fig. 6c). The loading of equal amounts of protein in the gels was confirmed by reprobing the membranes for neurofilament $200(N F$ 200) as shown in Figure $6 c$.

\section{Immunohistochemistry of spinal cord white matter}

Immunohistochemistry was performed on whole spinal cord sections with the goal of determining the subtypes of AMPA or KA receptors present in white matter and their cellular localization. We identified the presence of cells immunoreactive for GluR4, GluR6/7, or KA2 in spinal cord white matter (Fig. 7). Double labeling with GFAP identified the majority of these cells as astrocytes. Faint inconsistent labeling with GluR1 was seen. No GluR2/3 immunopositivity in spinal cord white matter was identified. Negative controls (omission of primary antibody and in some cases omission of secondary antibody) showed no immunostaining of any cellular elements (data not shown).

\section{DISCUSSION}

In the present study, we have shown that blockade of AMPA/KA but not NMDA receptors improved recovery of CAP amplitude after compressive injury to adult mammalian spinal cord white matter. In support of these findings, infusion of the agonist NMDA did not affect recovery of CAP amplitude after traumatic SCI, whereas administration of AMPA or kainic acid significantly accentuated post-traumatic axonal dysfunction. With AMPA/KA stimulation and injury alone, $\mathrm{Co}^{2+}$-positive glia were visualized in sections of dorsal column, providing evidence for the presence of $\mathrm{Ca}^{2+}$-permeable AMPA/KA receptors in CNS white matter. With immunohistochemistry and Western blot analysis, we characterized the presence of certain subtypes of AMPA (GluR4) and KA (GluR6/7 and KA2) receptors in thoracic spinal cord white matter. By double labeling with GFAP, these receptors were found directly on periaxonal astrocytes.

Glutamate receptor activation can increase the intracellular $\mathrm{Ca}^{2+}$ concentration in neurons and has been implicated in $\mathrm{Ca}^{2+}$. mediated cell death in various neurodegenerative disorders (Rothman and Olney, 1987; Regan and Choi, 1991). Ionotropic glutamate receptors are classified into those gated by NMDA and those activated by KA and AMPA. Although NMDA receptors are known to be highly calcium permeable, they are not known to be expressed on axons or glia; accordingly, their role in CNS white matter injury including SCI is doubtful. Thus, our finding that infusion of the agonist NMDA in conjunction with the co-agonist glycine did not exacerbate the extent of post-traumatic axonal dysfunction (Fig. 2a) or that the NMDA antagonist APV did not improve CAP amplitude after injury (Fig. $2 b$ ) is congruent with the biology of NMDA receptors. Furthermore, these findings are in agreement with the studies of Gomez-Pinella et al. (1989) and Faden and Simon (1988), who found that NMDA antagonists did not ameliorate the extent of tissue loss after traumatic SCI.

The rationale for examining the potential role of AMPA receptors in mediating $\mathrm{Na}^{+}$-dependent and $\mathrm{Ca}^{2+}$-induced spinal cord white matter degeneration is based on the observation of AMPA receptors, permeable to calcium, on astrocytes (Jensen and Chiu, 1993). Periaxonal glia, in particular astrocytes, are important in modulating axonal signaling (Kriegler and Chiu, 1993) and in regulating extracellular ionic perturbations. We have demonstrated that infusion of either AMPA or kainic acid attenuates CAP amplitude in an in vitro preparation of isolated dorsal column white matter (Fig. 4a,b). Furthermore, administration of the AMPA/KA receptor antagonists CNQX or NBQX or coapplication of AMPA/KA plus antagonists is associated with improved recovery of CAP amplitude after compressive injury (Fig. $3)$. The results of coapplication suggests that both AMPA and KA receptors are important in SCI; however, more specific antagonists are required to dissect these mechanisms in greater detail. The results are also in agreement with those of Gill et al. (1992), who found that NBQX was neuroprotective in a rat focal ischemia model, and Wrathall et al. (1994), who found that NBQX when administered by intramedullary injection into the rat spinal cord improved locomotor performance after SCI and was associated with sparing of white matter. It is noteworthy that the improvement of CAP amplitude with CNQX or NBQX solutions was not sustained. The affinity of NBQX for KA receptors is $\sim 30$ times less than its affinity for AMPA receptors (Sheardown et al., 1990). In contrast, CNQX affects both KA and AMPA receptors, with a slightly greater affect on the former. After $75 \mathrm{~min}$, the CAP amplitude gradually declined (Fig. $3 a, b$ ). When AMPA/KA plus antagonists were coapplied, these effects were sustained (Fig. $3 c$ ), which suggests that both AMPA and KA receptors are involved in traumatic white matter injury.

The majority of experiments conducted in this study were performed at $25^{\circ} \mathrm{C}$, because the dorsal column preparations re- 

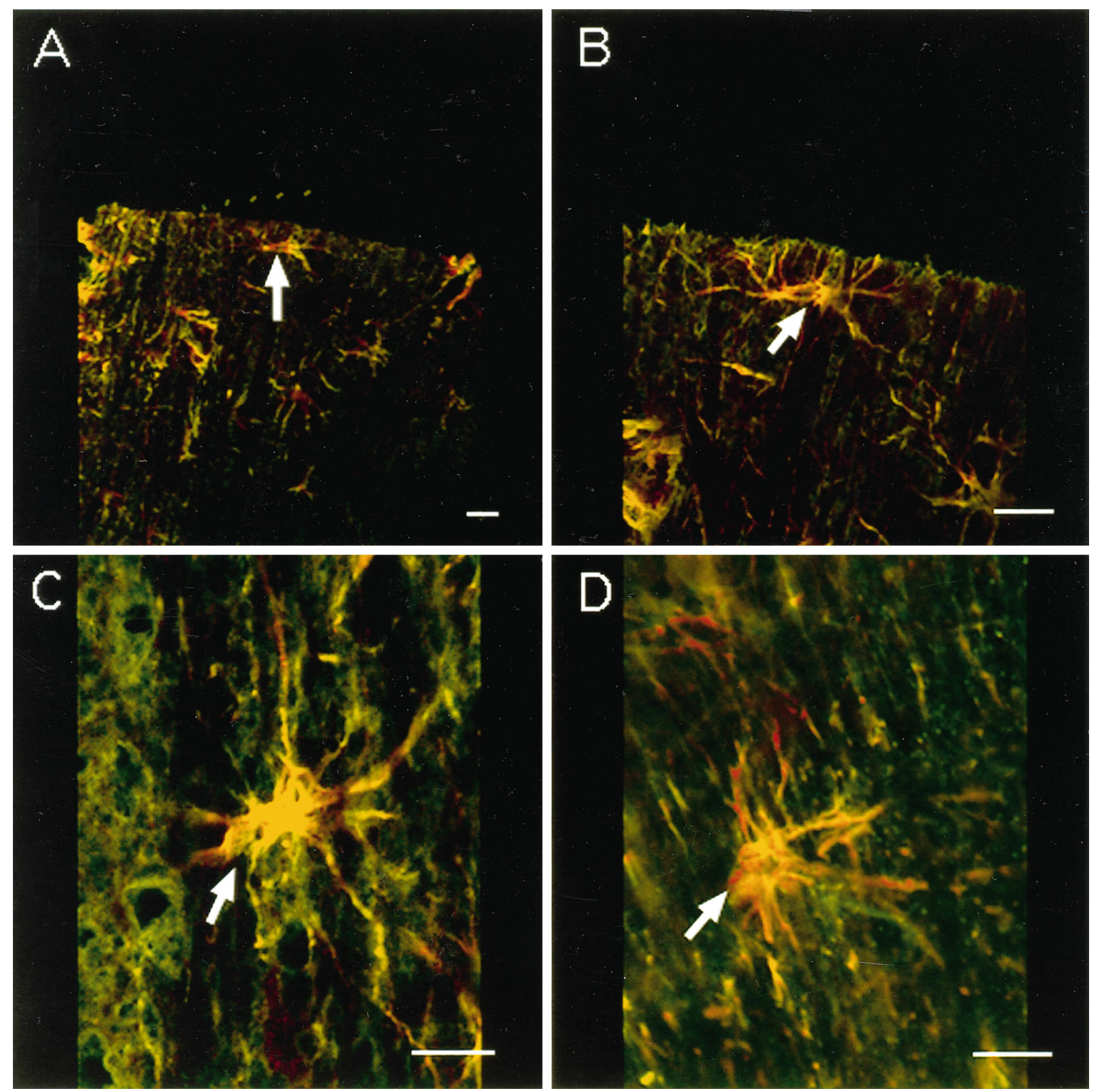

Figure 7. The presence of GluR4 $(A, B)$, GluR6/7 $(C)$, and KA2 $(D)$ immunoreactivity (FITC labeling shown as green) in $10 \mu \mathrm{m}$ sections of thoracic spinal cord dorsal column. Double labeling with GFAP (Texas Red) confirmed these immunopositive cells to be astrocytes (arrows). Scale bars, $50 \mu \mathrm{m}$.

main extremely physiologically stable under these conditions. Although hypothermia could provide some degree of neuroprotection, both control and test preparations were subjected to the same bath conditions. Accordingly, any neuroprotective effects of a hypothermic extracellular milieu would be controlled; however, to exclude this as a potentially confounding factor, selected experiments $(n=11)$ were conducted at $33^{\circ} \mathrm{C}$. At this temperature, stable recordings could be obtained. The results at $33^{\circ} \mathrm{C}$ were similar to data obtained at $25^{\circ} \mathrm{C}$, as has been reported previously (Agrawal and Fehlings, 1996).

KA-evoked elevation of $\left[\mathrm{Na}^{+}\right]_{\mathrm{i}}$ and $\left[\mathrm{Ca}^{2+}\right]_{\mathrm{i}}$ has been reported in several studies. Lower doses of kainic acid significantly increase the intracellular concentration of sodium and water (Coyle, 1983). This could be one source of neurotoxicity, because there is evidence that removing extracellular $\mathrm{Na}^{+}$or blocking $\mathrm{Na}^{+}$channels in the extracellular environment is neuroprotective (Stys et al., 1992; Agrawal and Fehlings, 1996). Moreover, in some neurons and glia the non-NMDA receptor channels are highly permeable to $\mathrm{Ca}^{2+}$ (Iino et al., 1990; Gilbertson et al., 1991; Burnashev et al., $1992 b)$. Furthermore, the differences in permeability of $\mathrm{Ca}^{2+}$ may be explained by the presence of different subtypes of AMPA/KA receptors in different tissues. With imaging techniques, Keller et al. (1992) demonstrated a large increase in $\left[\mathrm{Ca}^{2+}\right]_{\mathrm{i}}$ induced by $\mathrm{Ca}^{2+}$ influx through AMPA/KA receptor channels expressed in 
Xenopus oocyte. Burnashev et al. (1992a) showed that unedited homomeric GluR-B channels exhibit a high $\mathrm{Ca}^{2+}$ permeability in human embryonic kidney cells. It has also been shown that AMPA receptors that lack an edited GluR2 (GluR-B) subtype will be highly permeable to calcium. The present results, which show the absence of GluR2 subtypes in white matter glial cells, suggest that the AMPA receptors are highly calcium permeable.

In contrast to voltage-gated $\mathrm{Ca}^{2+}$ channels, $\mathrm{Ca}^{2+}$-permeable non-NMDA receptor channels are permeable to a wide range of other divalent cations, including $\mathrm{Ba}^{2+}, \mathrm{Mg}^{2+}, \mathrm{Sr}^{2+}$, and $\mathrm{Mn}^{2+}$ (Iino et al., 1990; Hollmann et al., 1991; Burnashev et al., 1992a), and are indirectly permeable to $\mathrm{Co}^{2+}$ (Pruss et al., 1991). In the present study, using the $\mathrm{Co}^{2+}$ uptake method we have demonstrated that $\mathrm{Ca}^{2+}$ permeable AMPA/KA receptors are found on glial cells and that these receptors may act as a major route for the $\mathrm{Ca}^{2+}$ entry (Fig. 5). Several explanations can account for the rise in $\left[\mathrm{Ca}^{2+}\right]_{i}$ with AMPA/KA receptor activation. First, AMPA/KA could activate two populations of channels: one with high permeability to $\mathrm{Ca}^{2+}$ and a nonlinear current-voltage $(I-V)$ relationship and the second with linear or outwardly rectifying $I-V$ relationships and low permeability to $\mathrm{Ca}^{2+}$ (Iino et al., 1990). Moreover, the main source of $\left[\mathrm{Ca}^{2+}\right]_{\mathrm{i}}$ elevation on application of $\mathrm{KA}$ could be from intracellular stores, i.e., a small influx of $\mathrm{Ca}^{2+}$ through KA-activated channels could cause $\mathrm{Ca}^{2+}$-induced $\mathrm{Ca}^{2+}$ release. Finally, activation of $\mathrm{Ca}^{2+}$ mobilizing systems, including inositol triphosphate-linked mechanism, has been described for nicotinic acetylcholine receptors (Grassi et al., 1993) and potentially could also apply to AMPA/KA receptors.

Non-NMDA ionotropic glutamate receptors seem to be restricted mainly to astrocytes in CNS white matter, although recent work on optic nerve suggests that a small population of O-2A glial precursors in adult CNS white matter express AMPA/KA receptors (Barres et al., 1990). There is evidence that periaxonal astrocytes modulate the ionic environment at the node of Ranvier (Usowicz et al., 1989) and can release substances to modulate excitability of axons. Indeed, axons are known to have GABA receptors, and O-2A glial progenitor cells can synthesize GABA (Barres, 1991), possibly in response to glutamate receptor activation (Gallo et al., 1991). AMPA/KA receptors (GluR1 and GluR3) also may be expressed on axons based on immunoelectron microscopic studies of the hippocampus (Martin et al., 1993) and the bed nucleus of the stria terminalis (Ginsberg et al., 1995). Our results demonstrate clearly that AMPA/KA receptors are present in spinal cord white matter. First, the cobalt staining method showed numerous $\mathrm{Co}^{2+}$-positive glia with AMPA and KA stimulation. Second, Western blot analysis demonstrated the presence of GluR4, GluR6/7, and KA2 immunoreactivity in spinal cord white matter. Finally, immunocytochemistry demonstrated numerous GFAP-positive periaxonal astrocytes double-labeled for GluR4, GluR6/7, and KA2 subtypes of AMPA or KA receptors. Thus, the non-NMDA ionotropic glutamate receptor effects in spinal cord axonal injury may be mediated by the GluR4, GluR6/7, and KA2 receptors on astrocytes.

\section{REFERENCES}

Agrawal SK, Fehlings MG (1995) Mechanisms of calcium mediated axonal injury after spinal cord trauma. Soc Neurosci Abstr 21:381.

Agrawal SK, Fehlings MG (1996) Mechanisms of secondary injury to spinal cord axons in vitro: role of $\mathrm{Na}^{+}, \mathrm{Na}^{+}-\mathrm{K}^{+}$ATPase, the $\mathrm{Na}^{+}-\mathrm{H}^{+}$ exchanger, and the $\mathrm{Na}^{+}-\mathrm{Ca}^{++}$exchanger. J Neurosci 16:545-552.

Ascher P, Nowak L (1988) Quisqualate- and kainate-activated channels in mouse central neurons in culture. J Physiol (Lond) 399:227-245.

Barres BA (1991) New roles for glia. J Neurosci 11:3685-3694.
Barres BA, Koroshetz WJ, Swartz KJ, Chun LLY, Corey DP (1990) Ion channel expression by white matter glia: the O-2A glial progenator cell. Neuron 4:507-524.

Bengtsson F, Siesjo BK (1990) Cell damage in cerebral ischemia: physiological, biochemical and structural aspects. In: Cerebral ischemia and resuscitation (Schurr A, Rigor BM, eds), pp 215-233. Boca Raton, FL: CRC.

Burgoyne RD (1991) High molecular weight microtubule associated proteins of brain. In: The neuronal cytoskeleton (Burgoyne RD, eds), pp 75-91. New York: Wiley.

Burnashev N, Monyer H, Seeburg PH, Sakmann B (1992a) Divalent ion permeability of AMPA receptor channels is dominated by the edited form of a single subunit. Neuron 8:189-198.

Burnashev N, Khodorova A, Jonas P, Helm PJ, Wisden W, Monyer H, Seeburg PH, Sakmann B (1992b) Calcium-permeable AMPA-kainate receptors in fusiform cerebellar glial cells. Science 256:1566-1570.

Coyle JT (1983) Neurotoxic action of kainic acid. J Neurochem 41:1-11.

Dolan EJ, Tator CH (1979) A new method for testing the force of clips for aneurysms or experimental spinal cord compression. J Neurosurg 51:229-233.

Faden AI, Simon RP (1988) A potential role for excitotoxins in the pathophysiology of spinal cord injury. Ann Neurol 23:623-626.

Fehlings MG, Nashmi R (1995) Assessment of axonal dysfunction in an in vitro model of acute compressive injury to adult rat spinal cord axons. Brain Res 677:291-299.

Gallo V, Patrizio M, Levi G (1991) GABA release triggered by the activation of neuron like non-NMDA receptors in cultured type 2 astrocytes is carrier mediated. Glia 4:245-255.

Gilbertson TA, Scobey R, Wilson M (1991) Permeation of calcium ions through non-NMDA glutamate channels in retinal bipolar cells. Science 251:1613-1615.

Gill R, Nordholm L, Lodge D (1992) The neuroprotective actions of 2,3-dihydroxy-6-7-sulfamoyl-benzo(f)quinoxaline (NBQX) in rat focal ischaemia model. Brain Res 580:35-43.

Ginsberg SD, Price DL, Blackstone CD, Huganir RL, Martin LJ (1995) The AMPA glutamate receptor GluR3 is enriched in oxytocinergic magnocellular neurons and is localized at synapses. Neuroscience 65:563-575.

Glaum SR, Holzwarth J, Miller RJ (1990) Glutamate receptors activate $\mathrm{Ca}^{2+}$ mobilization and $\mathrm{Ca}^{2+}$ influx into astrocytes. Proc Natl Acad Sci USA 87:3454-3458.

Goldberg MP, Choi DW (1993) Combined oxygen and glucose deprivation in cortical cell culture: calcium-dependent mechanisms of neuronal injury. J Neurosci 13:3510-3524.

Gomez-Pinella F, Tram H, Cotman CW, Nieto-Sampedro M (1989) Neuroprotective effect of MK-801 and U-50488H after contusive spinal cord injury. Exp Neurol 104:118-124.

Grassi F, Giovannelli A, Fucile S, Eusebi F (1993) Activation of the nicotinic acetylcholine receptor mobilizes calcium from caffeineinsensitive stores in $\mathrm{C} 2 \mathrm{C} 12$ mouse myotubes. Pflügers Arch 422:591-598.

Gu Y, Huang LYM (1991) Block of kainate receptor channels by $\mathrm{Ca}^{2+}$ in isolated spinal trigeminal neurons of rat. Neuron 6:777-784.

Hagiwara S, Byerly L (1981) Calcium channels. Annu Rev Neurosci 4:69-127.

Hollmann M, Hartley M, Heinemann S (1991) $\mathrm{Ca}^{2+}$ permeability of KA-AMPA-gated glutamate receptor channels depends on subunit composition. Science 252:851-854.

Holopainen I, Enkvist MOK, Akerman KEO (1989) Glutamate receptor agonists increase intracellular $\mathrm{Ca}^{2+}$ independently of voltage-gated $\mathrm{Ca}^{2+}$ channels in rat cerebellar granule cells. Neurosci Lett 98:57-62.

Iino M, Ozawa S, Tsuzuki K (1990) Permeation of calcium through excitatory amino acid receptor channels in cultured rat hippocampal neurons. J Physiol (Lond) 424:151-165.

Jensen AM, Chiu SY (1991) Differential intracellular calcium responses to glutamate in type 1 and type 2 cultured rat brain astrocytes. J Neurosci 11:1674-1684.

Jensen AM, Chiu SY (1993) Expression of glutamate receptor genes in white matter: developing and adult rat optic nerve. J Neurosci 13:1664-1675.

Keller BU, Hollmann M, Heinemann S, Konnerth A (1992) Calcium influx through subunits GluR1/GluR3 of kainate/AMPA receptor channels is regulated by cAMP dependent protein kinase. J EMBO 11:891-896. 
Kriegler S, Chiu SY (1993) Calcium signalling of glial cells along mammalian axons. J Neurosci 13:4229-4245.

Martin LJ, Blackstone CD, Levey AI, Huganir RL, Price DL (1993) AMPA glutamate receptor are differentially distributed in rat brain. Neuroscience 53:327-358.

Mayer ML, Westbrook GL (1987) Permeation and block of $N$-methyl-Daspartic acid receptor channels by divalent cations in mouse cultured central neurons. J Physiol (Lond) 394:501-527.

Mayer ML, MacDermott AB, Westbrook GL, Smith SJ, Barker JL (1988) Agonist- and voltage-gated calcium entry in cultured mouse spinal cord neurons under voltage clamp measured using arsenazo III. J Neurosci 7:3230-3244

McGurk JF, Roginski RS, Zukin RS, Bennett MVL (1991) Divalent ion permeability and pharmacology of cloned kainate/AMPA receptors expressed in oocytes. Soc Neurosci Abstr 17:335.

Miller RJ (1991) The revenge of the kainate receptor. Trends Neurosci 14:477-479.

Olney JW (1981) Kainic acid and other excitotoxins: a comparative analysis. In: Glutamate as a neurotransmitter (Di Chiara G, Gessa GL, eds), pp 375-384. New York: Raven.

Peterson GL (1977) A simplification of the protein assay method of Lowry et al. which is more generally applicable. Anal Biochem 83:346-356.

Pruss RM, Akeson RL, Racke MM, Wilburn JL (1991) Agonist-activated cobalt uptake identifies divalent cation-permeable kainate receptors on neurons and glial cells. Neuron 7:509-518.
Regan RF, Choi DW (1991) Glutamate neurotoxicity in spinal cord cell culture. Neuroscience 43:585-591.

Roberts-Lewis JM, Savage MJ, Marcy VR, Pinsker LR, Siman R (1994) Immunolocalization of calpain I-mediated spectrin degradation to vulnerable neurons in the ischemic gerbil brain. J Neurosci 14:3934-3944.

Rothman SM, Olney JW (1987) Excitotoxicity and the NMDA receptor. Trends Neurosci 10:299-302.

Sheardown MJ, Nielsen EO, Hansen AJ, Jacobsen P, Honore T (1990) 2,3-Dihydroxy-6-nitro-7-sulfamoyl-benzo(F)quinoxaline: a neuroprotectant for cerebral ischemia. Science 247:571-574.

Stys PK, Waxman SG, Ransom BR (1992) Ionic mechanisms of anoxic injury in mammalian CNS white matter: role of $\mathrm{Na}^{+}$channels and the $\mathrm{Na}^{+}-\mathrm{Ca}^{++}$exchanger. J Neurosci 12:430-439.

Tator CH, Fehlings MG (1991) Review of the secondary theory of acute spinal cord trauma with emphasis on vascular mechanisms. J Neurosurg 75:15-26.

Usowicz MM, Gallo V, Cull-Candy SD (1989) Multiple conductance channels in type- 2 cerebellar astrocytes activated by excitatory amino acids. Nature 339:380-383.

Wrathall JR, Choiniere D, Teng YD (1994) Dose-dependent reduction of tissue loss and functional impairment after spinal cord trauma with the AMPA/kainate antagonist NBQX. J Neurosci 14:6598-6607.

Wrathall JR, Teng YD, Choiniere D (1996) Amelioration of functional deficits from spinal cord trauma with systemically administered NBQX, an antagonist of non- $N$-methyl-D-aspartate receptors. Exp Neurol 137: $119-126$. 